\title{
TECHNOLOGICAL QUALITY OF WHEAT INFESTED WITH RHYZOPERTHA DOMINICA F. (COLEOPTERA: BOSTRICHIDAE)
}

Vesna Perišić1 ${ }^{*}$, Miroslav Hadnađev³, Vladimir Perišić ${ }^{1}$, Filip Vukajlović², Tamara Dapčević-Hadnađev ${ }^{3}$, Kristina Luković$^{1}$, Vera Đekić ${ }^{1}$

${ }^{1}$ Center of Small Grains, Kragujevac, Serbia

2University of Kragujevac, Faculty of Science, Kragujevac, Serbia

3 Institute of Food Technology, Novi Sad, Serbia

Due to its negative impact on the yield and quality of stored grains, the aim of this research was to study the influence of Rhyzopertha dominica F. on rheological properties of wheat flour obtained from grains infested by examined pest. A rheological laboratory device - Mixolab was employed in order to simulate the production process of bread (from the beginning of dough mixing until the end of bread baking). Wet gluten and gluten index, as significant flour quality parameters, were also determined. The flour of wheat varieties Planeta and Kruna was used in these experiments. The samples of both varieties infested with $R$. dominica (infested samples) were characterized and compared to their uninfested counterparts (control samples). Infested samples expressed a lower gluten index content, greater weakening of the gluten network upon mixing and heating, as well as lower starch gelatinization viscosity in comparison to control samples. Changes in the gluten index value were more pronounced in Planeta variety which was characterized with a higher degree of infestation. Determined changes in rheological properties of infested wheat were mainly dependent on a degree of infestation. However, a varietal dependency on the intensity of changes in technological quality cannot be neglected.
(ORIGINAL SCIENTIFIC PAPER ) UDC 633.11:632.7:543.2

Keywords: rheological properties, infestation, $R$. dominica, wheat varieties, Mixolab.

\section{Introduction}

Technological quality of wheat is defined by physical, chemical and rheological indicators of the quality, as well as baking properties. The great importance of wheat relies on the fact that during the milling process the flour and semolina are obtained. They represent the basic ingredients of the bread and other baking products and pasta. Wheat flour is a very complex natural material with the variable composition and properties depending on grain species, climatic conditions, the applied crop management, a milling method, and proper grain storage. Wheat with a higher content of grains damaged by pest or fungi results in the flour which does not form gluten with usual characteristics because of high proteolytic enzymes and their activators content. The flour from this kind of grains gives excessively stretchable, non-elastic and extremely liquid dough. Furthermore, such dough has the low gas retention capacity, poor structure and shape, while the obtained pastry is flattened and not risen enough [1]. Loaves of bread reduced the volume and the inappropriate texture [2].

The lesser grain borer, Rhyzopertha dominica F. (Coleoptera: Bostrichidae) is a very dangerous and harmful primary pest of the stored grains [3]. Economic importance of this pest species is pertinent, and according to its deleterious effect it comes right after the wheat weevil (Sitophilus granarius F.). The pest spends most of its life cycle (adult and larvae) in kernel and feeds with grain endosperm [3]. This results in physical and chemical composition changes of the grains which consequently affects rheological properties of the dough obtained from such infested grains. The damages affected by the presence of this pest are often so expressed that the stored crop is not eligible for human consumption and must be discarded from further usage and partially or completely destroyed [4-5].

Due to its negative impact on the yield and quality of the stored grains, the aim of this research was to study the influence of $R$. dominica on rheological properties of the wheat flour obtained from grains infested by the examined pest. In this study, the Mixolab laboratory device which simulates the production process of bread (from the beginning of dough mixing until the end of bread baking) was used. The Mixolab is a relatively new apparatus which is used for the characterization of the potential application of the examined flour in food industry according to obtained rheological properties of the tested dough [6-7]. Moreover, Mixolab parameters, as well as gluten quality characteristics, were related to a degree of grain infestation.

\section{Experimental}

Adults of $R$. dominica which were used in this experiment were grown on the whole wheat kernels under

\footnotetext{
*Author address: Vesna Perišić, Center of Small Grains,

Save Kovačevića 31, 34000 Kragujevac, Serbia

E-mail: vperisic@kg.ac.rs

The manuscript received: May, 16, 2018.

Paper accepted: May, 31, 2018.
} 
laboratory conditions (temperature $26 \pm 1{ }^{\circ} \mathrm{C}$ and relative humidity - RH $60 \pm 5 \%$.) in the Center for Small Grains in Kragujevac. In these experiments, 2 to 4 weeks of imago age were used. In order to investigate the influence of $R$. dominica on dough rheological properties, flour samples of wheat varieties Planeta and Kruna were used. Technological properties of wheat are shown in Table 1. Wheat samples characterized with the moisture content ranging from $11-12 \%$ were used for testing. The moisture content was established according to AACC method 44-11 [8] using Motomco moisture meter (Motomco Inc, 919, Canada).

Table 1. Technological properties of wheat varieties selected in the Center for Small Grains in Kragujevac, Serbia

\begin{tabular}{lll}
\hline \multicolumn{1}{c}{ Properties* } & Planeta & Kruna \\
\hline Farinograph & & \\
Water absorption (\%) & 61.8 & 57.2 \\
Dough development time (min) & 4.5 & 1.5 \\
Stability (min) & 7.5 & 1.0 \\
Degree of softening & 15 & 35 \\
Quality number & 90.7 & $68.3 ;$ \\
Quality group & $\mathrm{A} 1 . \mathrm{I}$ & $\mathrm{B} 1 . \mathrm{II}$ \\
Extensograph & & \\
Energy & 102 & 114 \\
Resistance (R) & 230 & 438 \\
Extensibility (Ext) & 194 & 143 \\
Ratio (R/Ext) & 1.2 & 3.1 \\
Bread score & 6.6 & 2.0 \\
\hline
\end{tabular}

${ }^{*}$ Results of Commission for approval of new varieties Ministry of agriculture, Serbia

Samples preparation for milling - Respecting optimal conditions for the growth and development of $R$. dominica described by Edde [3], a modified method according to Bodroža-Solarov et al. [9] was used in the research. At the beginning of the experiment, $250 \mathrm{~g}$ of the grain sample was measured for each variety and put in glass jars of 1 I volume. The samples of both wheat varieties contaminated with $R$. dominica (infested samples) were examined and compared with uninfested grains. All samples were stored in the thermostat at the constant temperature of $27^{\circ} \mathrm{C}$ and $\mathrm{RH} 55-60 \%$.

$R$. dominica was sieved after the 21 st day and the jars were returned in the thermostat and kept in controlled conditions for additional seven weeks. The number of progeny was determined after the expiration of this period. Imagoes were manually separated and a mass of the damaged and of intact grains was determined using the analytical scale (Mettler 609-B6, Zurich, Switzerland). The percentage of damaged grains was calculated as a ratio of damaged grains to intact grains.

After these measurements, the samples were homogenized by milling (laboratory mill Brabender, Duisburg). The flour was left for 20 days before further technological properties testing.

The dough was rinsed with $2 \%$ solution of $\mathrm{NaCl}$ in order to determine the wet gluten content. Determination of the wet gluten content was conducted using SRPS EN ISO 21415-2:2016 method [10].

Washed gluten was passed through the specially de- signed sieve of the centrifuge (2015, Perten Instruments, Huddinge, Sweden), under standardized conditions. The Gluten index $(\mathrm{Gl})$ represents the amount of wet gluten which was not passed through the sieve of the centrifuge in relation to the total mass of wet gluten, expressed in percentage.

Dough rheological properties of the examined wheat varieties were determined by Mixolab (Chopin, Paris, France) apparatus using ICC No. 173 method [11] and Chopin+ protocol. According to these measurements, the following parameters were obtained: WAMix- water absorption (\%); C1 - the initial maximum consistency $(\mathrm{Nm})$; DevMix- the dough development time (min); StabMix-dough stability (min); C2 - the minimum value of torque at the beginning of the heating stage $(\mathrm{Nm})$; C3- the maximum value of torque in the heating stage $(\mathrm{Nm}) ; \mathrm{C} 4-$ the minimum value of torque after the heating stage; C3-C4 - the hot paste stability (Nm); C4/C3 - the stability of starch paste, namely ratio between the minimum of torque after the heating stage and the maximum of torque in the heating stage; C5-C4 - retrogradation, namely the difference between the maximum of torque after cooling at $50{ }^{\circ} \mathrm{C}(\mathrm{C} 5)$ and the minimum value of torque after the heating stage $(\mathrm{Nm})$.

Recorded data were analyzed by the one-way analysis of variance. The significance of mean differences was determined according to Duncan test (for $p=0.05$ ). The percentage of the damaged grains (infestation) due to the activity of $R$. dominica was determined according to a mathematical formula proposed by FAO [12]:

$\%$ of damaged grains $=\frac{(\operatorname{TnxBo})-(\operatorname{ToxBn})}{\operatorname{Tn}(\mathrm{Bo}+\mathrm{Bn})} \times 10$

where $T n$ represents the mass of the grain at the beginning, To - mass of damaged grains, $B n$ - number of grains at the beginning, Bo-number of damaged grains.

\section{Results and discussion}

The number of progeny, together with the number of damaged grains, the mass of damaged grains and the percentage of damaged grains after separation of $R$. dominica progeny from wheat are presented in Table 2. The highest number of the progeny was recorded for Planeta variety which significantly influenced a higher content of damaged grains compared to Kruna variety (7.5\% vs. $3.1 \%$, respectively).

Although the values for the wet gluten content (WG) were not significantly changed upon infestation with $R$. dominica in both tested wheat varieties (Table 3 ), it should be mentioned that changes in this parameter for Planeta variety were more pronounced (from 20.90 to 19.85 for control and infested samples, respectively) compared with Kruna variety (from 18.80 to 18.40 , for control and infested samples, respectively). The value of gluten index $(\mathrm{Gl})$ of the infested Planeta variety sample was significantly lower compared with the control sample (from $99 \%$ to $85 \%$ ), while there was no significant 
decrease in GI value for other examined variety. The quality of the flour mostly depends on the gluten quality, whereby Đaković [13] stated that only higher differences in the content of wet gluten (for instance 4\%, and more) could be significant for the technological quality of the flour. According to Domenichini et al. [14], the changes in the quality of the flour obtained from infested wheat are largely dependent on the degree of the sample infestation. The investigation of Ozkay et al. [15] confirmed that the presence of $R$. dominica resulted in the reduction of the flour quality of soft and hard wheat: the gluten content and the sedimentation value were decreased. Moreover, the intensity of observed changes is also related to the infested variety and a degree of infestation. This is in agreement with the results of our research, where a decrease of WG and GI values depended on the degree of infestation.
Aja et al. [16] pointed out that a decrease in GI value represents a consequence of the activity of native proteolytic enzymes or the presence of grains infested by the pests. After the dough formation from the infested wheat flour sample,a proteolytic activity is rising which leads to the protein degradation and changes in the gluten structure.

The results of these investigations are in agreement with the results of Sanchez-Marinez et al. [17], who concluded that $R$. dominica influences the protein quality and can reduce the gluten ability to create a strong and continual dough network. Additionally, according to the results presented in this study, the influence of $R$. dominica could also be related to technological quality of wheat flour samples.

Table 2. The number of progeny, the number of damaged grains, the mass of damaged grains and the percentage of infestation after the separation of $R$. dominica progeny from wheat

\begin{tabular}{lllll}
\hline Variety & $\begin{array}{l}\text { Number of progeny } \\
\text { Planeta }\end{array}$ & $\begin{array}{c}\text { Number of damaged } \\
\text { grains }\end{array}$ & $\begin{array}{c}\text { Mass of damaged } \\
\text { grains }(\mathrm{g})\end{array}$ & $\begin{array}{c}\text { Damaged grains } \\
(\%)\end{array}$ \\
\hline Kruna & $4165.8 \pm 8.33^{\mathrm{a}}$ & $1644.5 \pm 5.93^{\mathrm{a}}$ & $53.7 \pm 0.44^{\mathrm{a}}$ & $7.5 \pm 0.21^{\mathrm{a}}$ \\
F & 22.29 & $659.0 \pm 2.8^{\mathrm{b}}$ & $20.4 \pm 0.48^{\mathrm{b}}$ & $3.1 \pm 0.21 \mathrm{~b}$ \\
$\mathrm{P}$ & $<0.05$ & 57.99 & 55.84 & 22.80 \\
& $<0.05$ & $<0.05$ & $<0.05$ \\
\hline
\end{tabular}

Table 3. Wet gluten content and gluten index values (\% $\%$ SG) of the tested wheat flour samples

\begin{tabular}{cllll}
\hline Variety & & & Wet gluten & Gluten index \\
\hline Planeta & Infested samples & Mean & $\mathbf{1 9 . 8 5}$ & $\mathbf{8 5 . 0 0}$ \\
& & Min & 19.80 & 82.00 \\
& & Max & 19.90 & 88.00 \\
& & SD & 0.07 & 4.24 \\
& & CV & 0.35 & 4.99 \\
& & Mean & $\mathbf{2 0 . 9 0}$ & $\mathbf{9 9 . 0 0}$ \\
& & Min & 20.80 & 99.00 \\
Kruna & & Max & 21.00 & 99.00 \\
& & SD & 0.14 & 0 \\
& & $C V$ & 0.67 & 0 \\
& & Mean & $\mathbf{1 8 . 8 0}$ & $\mathbf{9 7 . 0 0}$ \\
& & Min & 18.70 & 96.00 \\
& & Max & 18.90 & 98.00 \\
& & CD & 0.14 & 1.41 \\
& & $C V$ & 0.74 & 1.45 \\
& & Mean & $\mathbf{1 8 . 4 0}$ & $\mathbf{9 8 . 5 0}$ \\
& & Min & 18.50 & 98.00 \\
& & Max & 18.30 & 99.00 \\
& & SD & 0.14 & 0.70 \\
& & $C V$ & 0.76 & 0.71 \\
\hline
\end{tabular}

The evaluation of infested samples of Planeta variety by using Mixolab (Table 4) showed that water absorption and the dough development time increased (WAMix $59.29 \%$ against $57.45 \%$ and DevMix 2.70 min against $1.21 \mathrm{~min}$ ), while dough stability decreased (StabMix from $7.01 \mathrm{~min}$ to $3.33 \mathrm{~min})$. A significant difference in water absorption (55.90\% and $56.40 \%$ ) for Kruna variety was not established. In this variety, the dough development time, although being significantly lower in comparison to the dough development time of Planeta variety, was prolonged (DevMix 1.54 min against $1.13 \mathrm{~min}$ ) while the dough stability decreased (StabMix from $4.49 \mathrm{~min}$ to $4.07 \mathrm{~min})$.

According to Dubat [18] water absorption depends on the moisture content of the flour, the amount and quality of proteins, the content of intact and damaged starch granules, as well as the pentosan content, the size of the flour particles etc. Therefore, it can be concluded that higher water absorption of infested samples of Planeta variety could be due to a significantly higher amount of damaged and broken wheat grains. Higher WAMix value is desirable in milling and baking industry. However, this research has shown that the increased water absorption caused by pest infestation is unfavourable. It means that the values of water absorption must be in balance with the protein and moisture content in flour, damaged starch, and the ash content [19].

Infestation of wheat by $R$. dominica caused a prolonged dough development time and decreased stability of wheat dough, which suggests the increased enzymatic activity of flour and unstable dough. The enzymatic activity affected the degradation of the gluten network and/ or changes in carbohydrates complex which resulted in reduced ability of dough for keeping the initially bound water and consequently provoked dough softening. Aforementioned changes were caused by the fact that $R$. dominica was primarily feeding on endosperm [15] which is mostly comprised of carbohydrates, as well as grain storage proteins [20].

The obtained results are in agreement with the research of Cortezrocha et al. [1] who investigated rheological properties of the flour and bread produced from 
wheat infested with R. dominica. They found a higher water absorption capacity, a higher degree of softening and less stability of the dough during mixing. Ozkaya et al. [15]. determined that Farinograph's parameters such as water absorption and dough stability were slightly decreased, the dough development time was significantly decreased while the degree of softening was increased, as a result of $R$. dominica infestation.
The obtained results are in disagreement with findings of Domenichini et al. [14] who examined the influence of $S$. granarius and $R$. dominica on rheological properties of durum wheat and semolina. According to these authors, there were no significant changes in rheological parameters caused by infestation with the tested pests, which was explained by limited infestation of wheat by used storage pests.

Table 4. Minimum, maximum and average values of mixolab indicators of the flour quality obtained from infested wheat with $R$. dominica (expressed for varieties)

\begin{tabular}{|c|c|c|c|c|c|c|c|c|c|c|c|c|c|}
\hline \multirow[t]{21}{*}{ Variety } & & WAMix & DevMix & StabMix & C1 & $\mathrm{C} 2$ & C1-C2 & C3 & C4 & C5 & C4/C3 & C3-C4 & C5-C4 \\
\hline & Mean & 59.29 & 2.70 & 3.33 & 1.125 & 0.16 & 0.965 & 1.41 & 1.355 & 1.79 & 0.96 & 0.05 & 0.44 \\
\hline & Min & 59.23 & 2.68 & 3.20 & 1.11 & 0.15 & 0.96 & 1.40 & 1.34 & 1.78 & 0.96 & 0.06 & 0.44 \\
\hline & Max & 59.35 & 2.72 & 3.47 & 1.14 & 0.17 & 0.97 & 1.42 & 1.37 & 1.80 & 0.96 & 0.05 & 0.47 \\
\hline & SD & 0.08 & 0.03 & 0.19 & 0.02 & 0.01 & 0.01 & 0.01 & 0.02 & 0.01 & 0 & 0 & 0.02 \\
\hline & $\mathrm{CV}$ & 0.13 & 1.11 & 5.70 & 1.78 & 6.25 & 1.04 & 0.71 & 1.48 & 0.56 & 0 & 0 & 4.54 \\
\hline & Mean & 57.45 & 1.215 & 7.01 & 1.095 & 0.37 & 0.725 & 1.85 & 1.705 & 2.49 & 0.92 & 0.09 & 0.79 \\
\hline & Min & 57.40 & 1.20 & 6.99 & 1.09 & 0.36 & 0.72 & 1.84 & 1.69 & 2.48 & 0.92 & 0.15 & 0.79 \\
\hline & Max & 57.49 & 1.23 & 7.03 & 1.10 & 0.38 & 0.73 & 1.86 & 1.72 & 2.50 & 0.92 & 0.14 & 0.78 \\
\hline & SD & 0.06 & 0.02 & 0.03 & 0.01 & 0.01 & 0.01 & 0.01 & 0.02 & 0.01 & 0 & 0.01 & 0.01 \\
\hline & $\mathrm{CV}$ & 0.10 & 1.65 & 0.43 & 0.91 & 2.70 & 1.38 & 0.54 & 1.17 & 0.40 & 0 & 11.11 & 1.27 \\
\hline & Mean & 55.90 & 1.54 & 4.07 & 1.145 & 0.20 & 0.945 & 1.58 & 1.545 & 2.25 & 0.97 & 0.03 & 0.71 \\
\hline & Min & 55.80 & 1.53 & 3.93 & 1.13 & 0.19 & 0.94 & 1.59 & 1.54 & 2.24 & 0.97 & 0.05 & 0.70 \\
\hline & Max & 56.00 & 1.55 & 4.21 & 1.06 & 0.21 & 0.95 & 1.57 & 1.55 & 2.26 & 0.97 & 0.02 & 0.71 \\
\hline & SD & 0.14 & 0.01 & 0.20 & 0.05 & 0.02 & 0.01 & 0.01 & 0.01 & 0.01 & 0 & 0.02 & 0.01 \\
\hline & $\mathrm{CV}$ & 0.25 & 0.65 & 4.91 & 4.37 & 10.00 & 1.06 & 0.63 & 0.65 & 0.44 & 0 & 66.67 & 1.41 \\
\hline & Mean & 56.49 & 1.135 & 4.49 & 1.11 & 0.355 & 0.755 & 1.995 & 2.00 & 2.935 & 1.0 & 0.00 & 0.93 \\
\hline & Min & 56.48 & 1.13 & 4.37 & 1.11 & 0.35 & 0.76 & 1.99 & 1.99 & 2.93 & 1.0 & 0.00 & 0.94 \\
\hline & Max & 56.50 & 1.14 & 4.62 & 1.11 & 0.36 & 0.75 & 2.00 & 2.01 & 2.94 & 1.0 & 0.00 & 0.93 \\
\hline & SD & 0.01 & 0.01 & 0.18 & 0 & 0.01 & 0.01 & 0.01 & 0.01 & 0.01 & 0 & 0.00 & 0.01 \\
\hline & $\mathrm{CV}$ & 0.02 & 0.88 & 4.01 & 0 & 2.82 & 1.32 & 0.50 & 0.50 & 0.34 & 0 & 0 & 1.07 \\
\hline
\end{tabular}

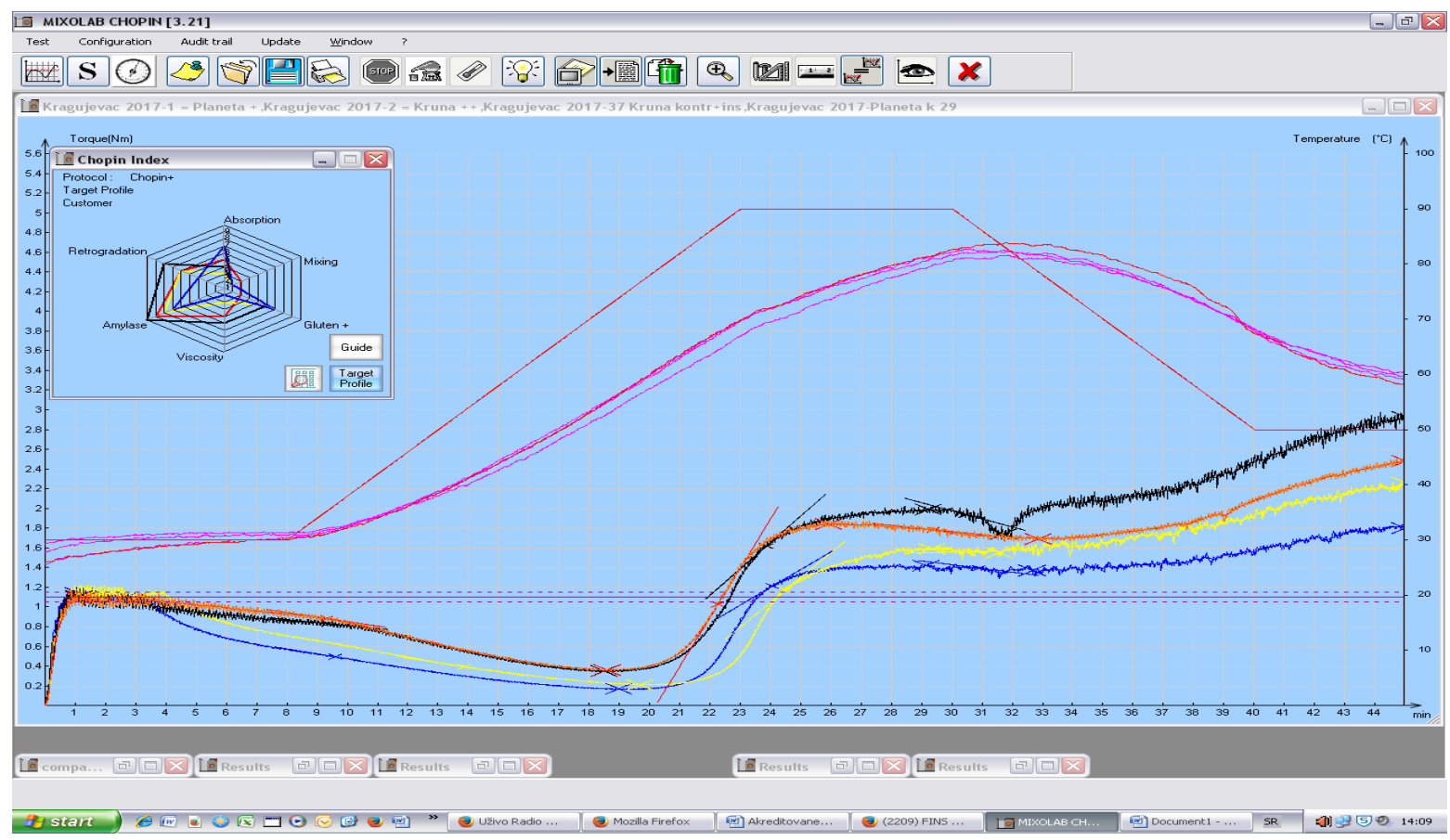

Figure 1. Mixolab curve of wheat varieties Planeta and Kruna: control variety Planeta $\square$, infested variety Planeta , control variety Kruna $\square$, infested variety Kruna and temperature profile 
The samples of both wheat varieties (Planeta and Kruna) infested with $R$. dominica expressed significant changes in obtained Mixolab parameters (Figure 1). Higher values of parameter $\mathrm{C} 1-\mathrm{C} 2$ revealed the gluten network disruption in infested samples. The sample with a higher amount of damaged grains expressed a more pronounced decrease in C2 value, which was in agreement with the results of gluten index determination (Table $3)$. Infested samples of both examined wheat varieties expressed lower stability and more intensive weakening of the gluten complex during mixing, especially during the heating stage (Table 4; Figure 1). Expressed changes were more prominent for Planeta variety.

The influence of $R$. dominica presence in the samples of both examined wheat varieties was especially pronounced for rheological parameters which are related to starch quality. The presence of $R$. dominica significantly influenced changes in parameters $\mathrm{C} 3$ to $\mathrm{C} 5$, which also had the influence on derived parameters responsible for starch quality (decreased viscosity, lower gelatinization temperature, decreased dough resistance, lower starch paste stability, higher amylase activity, decreased retrogradation). These changes were influenced by the wheat variety (Table 4; Figure 1).

Dough viscosity upon heating depends on a starch structure, the starch damage content, the amylase activity, the amount of water, lipids as well as starch-protein interactions [18]. Due to abovementioned, decreased values of $\mathrm{C} 3$, as well as C4 are expected for the infested sample, since this is an indicator of a higher activity of amylase caused by the presence of $R$. dominica. The pests damaged the starch granules during their feeding resulting in starch which is more susceptible to the a-amylase activity i.e. enzymatic reactions were more intense, which caused lower stability of starch paste.

Furthermore, infested samples had lower values of viscosity as a consequence of a higher damage of starch granules by the pests i.e. a higher activity of amylase which can cause pronounced starch liquefaction.

The influence of $R$. dominica infestation on a retrogradation degree can be observed in Figure 1. Although a lower retrogradation value is usually related to prolonged bread storage stability, it does not necessarily mean that the bread produced from such flour would be fresh for a longer period of time.

There is a lack in research regarding the influence of the pest infestation on rheological properties of the starch component, except for Domenichini et al. [14] who determined that the falling number changed upon wheat infestation with $S$. oryzae and $R$. dominica, and that it was cultivar and infestation intensity dependent. The falling number value was increased in the first but decreased in the second tested variety as a consequence of more intense infestation.

\section{Conclusion}

The results of the presented research revealed that $R$. dominica wheat infestation significantly deteriorates the technological quality of the flour. Since this is a primary pest in the storage, it is necessary to take all measures of protection in order to keep a good technological quality of wheat. Different levels of infestation of examined varieties indicate the necessity of growing wheat varieties tolerant to infestation within integrated measures of protection.

\section{Acknowledgements}

This study was carried out within a project supported by the Ministry of Education, Science and Technological Development of the Republic of Serbia, Grant No TR 31007, OI 173038.

\section{References}

[1] M.O. Cortezrocha, R.I. Sanchezmarinez, F. Ortegadorame, M. Moralevaldes, M.I. Silveira, End-use quality of flour from Rhyzopertha dominica infested wheat. Proceedings Cereal chemistry, 74 (4) (1997) 481 - 483.

[2] G. Hariri, P. Williams, F. El-Haramein, Influence of pentatomid insects on the physical dough properties and two-layered flat bread baking quality of syrian wheat. Journal of cereal science, 31 (2) (2000) 111-118.

[3] P. Edde, A review of the biology and control of Rhyzopertha dominica (F.) the lesser grain borer. Journal of Stored Products Research, 48 (2012) 1-18.

[4] D.P. Rees, Insects of Stored Products. (Edc). Manson Publishing, Ltd., UK. (2004), p. 23-44.

[5] T. Stadler, M.Buteler, K. Weaver, Novel use of nanostructured alumina as an insecticide. Pest Management Science, 66 (2010) 577-579.

[6] T. Dapčević Hadnađev, A. Torbica, M. Pojić, M. Hadnađev, The role of empirical rheology in flour quality control. In: I. Akyar (Ed.), Wide spectra of quality control Rijeka: InTech, Croatia (2011) pp. 335-360.

[7] T. Dapčević Hadnađev, Uticaj dodatka emulgujućih skrobova na tehnološke karakteristike testa i kvalitet hleba. Doktorska disertacija, Tehnološki fakultet, Novi Sad, 2013.

[8] AACC, Approved Methods of American Association of Cereal Chemists AACCI Method 44-11.01. AACC, St. Paul, MN St. Paul, MN, 2003.

[9] M. Bodroža-Solarov, P. Kljajić, G. Andrić, B.Filipčev, Lj. Dokić, Quality parameters of wheat grain and flour as influenced by treatments with natural zeolite and diatomaceous earth formulations, grain infestation status and endosperm vitreousness. Journal of Stored Products Research, 51 (2012) 61-68.

[10] SRPS metod, Institut za standarizaciju Srbije Pšenica i pšenično brašno. Sadržaj glutena. Deo 2: Određivanje vlažnog glutena i gluten indeksa mehaničkim načinima. Metod SRPS EN ISO 21415-2:2016, Beograd, Srbija, 2016.

[11] ICC Standard methods, International association for cereal science and technology, Whole Meal and Flour from $T$. aestivum - Determination of Rheological Behavior 
as a Function of Mixing and Temperature Increase. ICC standard method No. 173. ICC, Vienna, Austria, 2011.

[12] FAO, Towards integrited commodity and pest management in grain storage: A training manual for application in humid tropical storage, 1992.

[13] Lj. Đaković, Faktori kvaliteta pšeničnog brašna, Pšenično brašno (4th ed.). Novi Sad, Srbija: Zavod za tehnologiju žita i brašna, Tehnološki fakultet, 1997.

[14] G. Domenichini, M. Pagani, D. Fogliazza, Infestations of Sitophilus granarius (L.) and Rhyzoperta dominica (F.) on durum wheat, and their influence on the rheological characteristiks of the semolina. Proceedings of the 6th International Working Conference on Stored Product Protection, Canberra, Australia, 2 (1994) 689-694.

[15] H. Ozkaya, B. Ozkaya, A. Colakoglu, Technological properties of a variety of soft and hard bread wheat infested by Rhyzopertha dominica (F.) and Tribolium confusum du Val. Journal of Food, Agriculture and Environment, 7 (3-4) (2009) 166-172.

[16] S. Aja, G. Perez, C. M. Rosell, Wheat damage by Aelia spp. and Erygaster spp.: effects on gluten and watersoluble compounds released by gluten hydrolysis. Journal of Cereal Science, 39 (2004) 187-193.
[17] R.I. Sanches-Marines, M.O. Cortez-Rocha, F. OrtegaDorame, M. Morales-Valdes, M.I. Silveira, End-use quality of flour from Rhyzopertha dominica infested wheat. Cereal Chemistry, 74 (1997) 481-483.

[18] A. Dubat, The mixolab. In: Dubat, A., Rosell, C.M., Gallagher, E., (edc): Mixolab. A new approach to rhealogy. AACC Internacional, Minesota, USA 2013, p. 3-13.

[19] A. Dubat, O. Le Brun, S. Geoffroy, M. Tulbek, C. Hall, A. Freier, Factors Affecting Mixolab Performance. In: Dubat, A., Rosell, C.M., Gallagher, E., (edc): Mixolab. A new approach to rhealogy. AACC Internacional, Minesota, USA 2013, p. 15-22.

[20] O. Serna-Saldivar, Chemical composition of cereal grains. In: Serna-Saldivar, O. (ed): Cereal Grains: Properties, Processing, and Nutritional Attributes. Press Taylor \& Francis Group 2010,p. 92-108.

\section{Izvod \\ TEHNOLOŠKI KVALITET PŠENICE INFESTIRANE SA RHYZOPERTHA DOMINICA F.}

Vesna Perišić ${ }^{1}$, Miroslav Hadnađev ${ }^{3}$, Vladimir Perišić ${ }^{1}$, Filip Vukajlović2 Tamara Dapčević-Hadnađev ${ }^{3}$, Kristina Luković ${ }^{1}$, Vera Đekić ${ }^{1}$

(ORIGINALNI NAUČNI RAD)

UDK 633.11:632.7:543.2

\footnotetext{
1 Centar za strna žita, Kragujevac, Serbia

2 Univerzitet u Kragujevcu, Prirodno-matematički fakultet, Kragujevac, Srbija

3 Institut za prehrambene tehnologije, Novi Sad, Srbija
}

Zbog negativnog uticaja na prinos i kvalitet uskladištenog žita, cilj istraživanja je proučavanje uticaja Rhyzoperta dominica F. na reološke osobine pšeničnog brašna dobijenog od zrna infestiranog ispitivanom štetočinom. Za simulaciju proizvodnje hleba (od zamesa do krajnjeg proizvoda - hleba) korišćen je reološki laboratorijski uređaj - Mixolab. Takođe, određen je i sadržaj vlažnog glutena i gluten indeks koji su značajni parametri kvaliteta brašna. $U$ eksperimentu je korišćeno brašno sorti pšenice Planeta i Kruna. Ispitani su uzorci obe sorte infestiranih sa R. dominica (infestirani uzorci) i upoređeni sa odgovarajućim neinfestiranim uzorcima (kontrola). U poređenju sa kontrolnim uzorcima, infestirani uzorci pokazali su manji sadržaj glutena, veće slabljenje glutenske mreže prilikom mešenja i zagrevanja, kao i manji viskozitet i želatinizaciju skroba. Promene u vrednosti gluten indeksa bile su izraženije kod sorte Planeta kod koje je utvrđen veći procenat infestacije.Utvrđene promene u reološkim osobinama infestirane pšenice zavisile su, prvenstveno, od stepena infestacije pšenice. Međutim, intenzitet promena tehnološkog kvaliteta uslovljen je i uticajem sorte, koji ne može biti zanemaren.
KIjučne reči: tehnološki kvalitet, infestacija, R. dominica, sorte pšenice, Miksolab 